\title{
Keyword Index Volume 6 (1998)
}

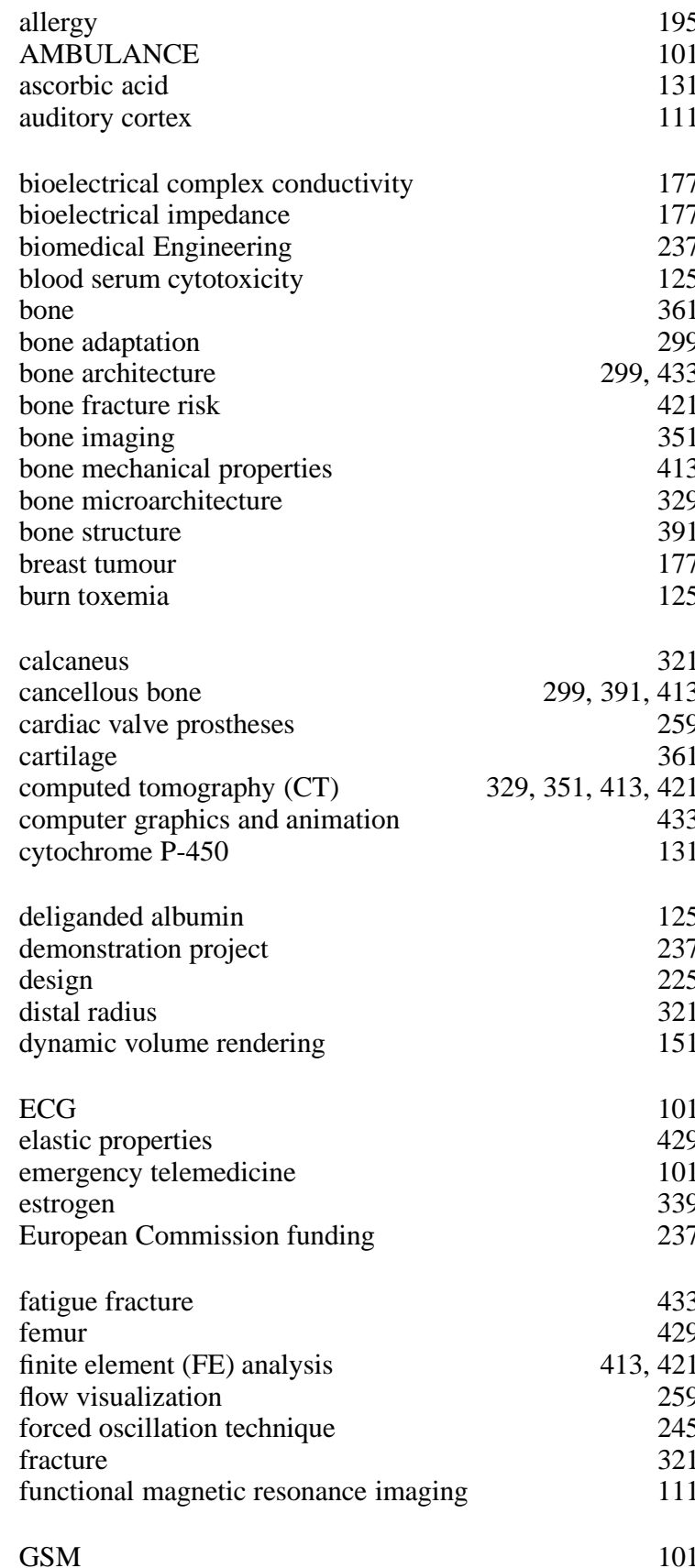

hardness $\quad 429$

high-affinity receptor for IgE 195

human serum albumin $\quad 125$

image processing $\quad 111$

immunoglobulin (Ig)E 195

infant 225

in vitro testing 259

lamella $\quad 429$

laser Doppler anemometry $\quad 259$

life sciences $\quad 237$

magnetic resonance imaging $151,321,351,413$

mechanical bone properties 421

medical database 101

medical devices $\quad 225$

medical images 101

micro tomography 391

micro-computed tomography $(\mu \mathrm{CT}) \quad 361,433$

microdamage 433

microtomography 339

monooxygenase system 131

MR microscopy $\quad 361$

muscle tone 245

NDEA-induced hepatocarcinogenesis $\quad 131$

NDEA precursors 131

neonatal intensive care $\quad 225$

NICU 225

obstructive apnea prediction $\quad 245$

obstructive sleep apnea syndrome 245

osteoarthritis 361

osteoclast 403

osteoporosis 299, 321, 339, 361, 413, 433

parasitic infestations 195

parents 225

principal stress analysis 259

quantitative bone morphology $\quad 329$

rat model 339

segmentation techniques $\quad 351$

synchrotron-CT 391

technology assessment 225

torsion 403 
trabecular bone

trabecular bone failure

trabecular bone micro-architecture

trabecular bone structure
339,429

433

321

329,421 upper airway wall compliance

245

vascular calcification

velocity profiles 259

wall motion analysis 